\title{
Symposium review: Effect of post-pasteurization contamination on fluid milk quality ${ }^{1}$
}

\author{
Nicole H. Martin, ${ }^{2}$ Kathryn J. Boor, and Martin Wiedmann \\ Milk Quality Improvement Program, Department of Food Science, Cornell University, Ithaca, NY 14853
}

\begin{abstract}
Fluid milk quality in the United States has improved steadily over the last 2 decades, in large part due to the reduction in post-pasteurization contamination (PPC). Despite these improvements, some studies suggest that almost $50 \%$ of fluid milk still shows evidence of PPC with organisms that are able to grow at $6^{\circ} \mathrm{C}$, even though PPC may be much less frequent in some facilities. Several gram-negative bacteria, when introduced as PPC, can grow rapidly at refrigeration temperatures around $6^{\circ} \mathrm{C}$ and can lead to bacterial levels above 20,000 $\mathrm{cfu} / \mathrm{mL}$ (the regulatory limit for bacterial numbers in fluid milk in the United States) and spoilage that can be detected sensorially within 7 to $10 \mathrm{~d}$ of processing. Importantly, however, storage temperature can have a considerable effect on microbial growth, and fluid milk stored at $4^{\circ} \mathrm{C}$ and below may show considerably delayed onset of microbial growth and spoilage compared with samples stored at what may be considered mild abuse $\left(6^{\circ} \mathrm{C}\right.$ and above). Notable organisms that cause PPC and grow at refrigeration temperatures include psychrotolerant Enterobacteriaceae and coliforms, as well as Pseudomonas. These organisms are known to produce a variety of enzymes that lead to flavor, odor, and body defects that can ultimately affect consumer perception and willingness to buy. Detecting PPC in high temperature, short time, freshly pasteurized fluid milk can be challenging because PPC often occurs sporadically and at low levels. Additionally, indicator organisms typically used in fluid milk (i.e., coliforms) have been shown to represent only a fraction of the total PPC. Recent studies indicate that coliforms account for less than $20 \%$ of the total gram-negative organisms introduced into fluid milk after pasteurization. In contrast, Pseudomonas, which is not a coliform and there-
\end{abstract}

\footnotetext{
Received June 15, 2017.

Accepted September 14, 2017.

${ }^{1}$ Presented as part of the Dairy Foods Symposium: Emerging Research and Insights to Drive Innovations in Fluid Milk at the ADSA Annual Meeting, Pittsburgh, Pennsylvania, June 2017.

${ }^{2}$ Corresponding author: nhw6@cornell.edu
}

fore is not detected using coliform media, is the most commonly isolated genus in PPC fluid milk. To reduce PPC, processors must (1) use testing methods that can detect both coliforms and non-coliform gram-negatives (i.e., Pseudomonas) to understand true contamination rates and patterns, and (2) establish cleaning and sanitation protocols and employee and management behaviors that target persistent and transient PPC organisms.

Key words: fluid milk, post-pasteurization contamination, Pseudomonas, sanitation, Enterobacteriaceae

\section{INTRODUCTION}

Raw milk, even when produced under ideal circumstances, has a diverse bacterial ecology that reflects the lifestyle of the animal and the environment in which the commodity is produced. A wide range of gram-positive and gram-negative bacteria, pathogens, spoilage bacteria, and organisms that are commensal with the animal or cause animal disease are found in raw milk. Fortunately, pasteurization, which was widely adopted in the United States in the 1940s, reduces the levels of many of these organisms by up to 6 orders of magnitude (Villamiel and de Jong, 2000). Certain heat-resistant or thermoduric bacteria (e.g., Micrococcus) are capable of surviving pasteurization conditions (e.g., $72^{\circ} \mathrm{C} / 15 \mathrm{~s}$ ) in vegetative form, but these organisms are typically not able to grow under refrigeration (Gleeson et al., 2013). Additionally, spore-forming bacteria can survive pasteurization in spore form; importantly, several aerobic sporeformers that can grow under refrigeration conditions have been identified in both raw milk and HTST-pasteurized fluid milk (Ivy et al., 2012). When post-pasteurization contamination (PPC) occurs with organisms that can grow at refrigeration temperatures, the gram-negative organisms introduced typically cause spoilage and reach levels above the Pasteurized Milk Ordinance (PMO) limit of 20,000 cfu/mL before growth of psychrotolerant sporeformers occurs and appear to outcompete these sporeformers. In the absence of PPC with gram-negative, psychrotolerant organisms, aerobic psychrotolerant sporeformers present in raw milk typi- 
cally grow to spoilage levels after $14 \mathrm{~d}$ at $6^{\circ} \mathrm{C}$ (Ranieri and Boor, 2009). The predominant spore-forming bacteria capable of growing at refrigeration temperatures are certain strains of Paenibacillus and Viridibacillus, along with Bacillus weihenstephanensis (Ivy et al., 2012). We might expect that much of the fluid milk supply would be spoiled by these aerobic spore-forming bacteria that originate in raw milk and survive pasteurization, yet almost $50 \%$ of the fluid milk supply shows evidence of contamination with heat-labile gram-negative bacteria that originate from the processing facility environment and recontaminate fluid milk after pasteurization.

Post-pasteurization contamination of fluid milk with psychrotolerant spoilage bacteria plays a significant role in limiting the quality and shelf life of conventionally pasteurized fluid milk. From the earliest days of pasteurization, recontamination of fluid milk after pasteurization has been identified as a problem. In 1920, milk inspectors were urged by Russel S. Smith of the Department of Agriculture to "not rest assured of a safe product because of the mere presence of a milk pasteurizing plant in their city. Special attention must be given to the operation of such a plant in view of the fact that unless it is properly operated it may become a chance source of infection" (Smith, 1920). Smith goes on to outline locations within the processing facility that should receive particular attention to prevent recontamination; namely, pumps, bottling machines, bottles, and milk cans (Smith, 1920). Despite the passage of nearly a century since the above advice to the dairy industry, PPC remains an important cause of fluid milk spoilage. This review focuses on the effects of PPC on fluid milk quality with special attention paid to the organisms commonly responsible for PPC, where they are typically introduced into fluid milk, and diagnostic tools for detecting and tracking them in product and processing environments.

\section{PSEUDOMONAS IS THE PRIMARY CAUSATIVE AGENT OF PPC IN FLUID MILK}

Pasteurization is designed to reduce the populations of the most heat-resistant vegetative pathogen found in milk, Coxiella burnetii, to levels that would not pose a public health risk (Holsinger et al., 1997). The resultant pasteurization parameters, a minimum of $72^{\circ} \mathrm{C}$ for 15 $\mathrm{s}$ for HTST processing, are reported to deliver a considerable reduction in psychrotolerant gram-negative bacteria (Champagne et al., 1994), and at least a 6-log reduction in some species of Pseudomonas (Villamiel and de Jong, 2000). Therefore, the presence of Pseudomonas and other gram-negative bacteria in pasteurized fluid milk is typically an indication that a contami- nation event has occurred post-processing. However, pasteurization failures and presence of high levels of gram-negative bacteria (with subsequent survival of pasteurization of some bacterial cells) in raw milk may also be responsible for presence of gram-negative bacteria in finished HTST products. The PMO limits total bacterial counts in grade ' $\mathrm{A}$ ' commingled raw milk to $300,000 \mathrm{cfu} / \mathrm{mL}$ (FDA, 2015). However, if this raw product is held for an extended period of time or at an elevated temperature before pasteurization, bacterial numbers may reach concentrations where even a 6 - $\log$ reduction would result in residual bacterial cells in pasteurized finished product. Although these deviations (i.e., pasteurization failure and very high pre-pasteurization bacterial levels) are less likely to be an issue in countries with well-developed and sophisticated dairy industries, high levels of gram-negative bacteria in raw milk are not unusual in countries that lack effective on-farm cooling practices and an effective farm-to-processing plant refrigeration chain.

Four primary groups of psychrotolerant bacteria are important in PPC of fluid milk (Table 1): (1) Pseudomonas; (2) coliforms; (3) non-Pseudomonas, noncoliform gram-negative bacteria; and (4) gram-positive spore-forming bacteria. Pseudomonas is, by far, the most commonly reported organism responsible for PPC of HTST fluid milk in the United States (Ranieri and Boor, 2009; Martin et al., 2011b) and globally, including Sweden (Ternström et al., 1993; Eneroth et al., 1998), Australia (Juffs, 1973; Deeth et al., 2002), the UK (Schröder, 1984; Stevenson et al., 2003), and others. Several factors contribute to the success of Pseudomonas as an agent of PPC, the first being its ability to grow rapidly at low temperatures (Ternström et al., 1993). Ranieri and Boor (2009) reported that samples of HTST fluid milk contaminated with Pseudomonas had significantly higher bacterial numbers by $7 \mathrm{~d}$ after pasteurization than samples lacking PPC, with those samples contaminated with Pseudomonas reaching the PMO limit of $20,000 \mathrm{cfu} / \mathrm{mL}$ at $\mathrm{d} 8$ after pasteurization, on average, compared with d 15 for samples with no PPC but with presence of psychrotolerant sporeformers. Trmčić et al. (2015) demonstrated that various Pseudomonas strains were capable of growing more than 4 $\log \mathrm{cfu} / \mathrm{mL}$ over $21 \mathrm{~d}$ at a slightly stressed refrigeration temperature (i.e., $6^{\circ} \mathrm{C}$ ). Additionally, Pseudomonas are known to be particularly adept at outcompeting other spoilage microorganisms due in part to the ability of many strains to produce antibacterial and antifungal agents and siderophores (Gram et al., 2002), which are excreted into the growth medium where they bind and solubilize iron. Pseudomonas produce a variety of siderophores, notably pyoverdin (Brown and Luke, 
2010). Pseudomonas fluorescens has been described as the predominant (Law, 1979; Dogan and Boor, 2003; Brown and Luke, 2010) and most important species of Pseudomonas found in HTST pasteurized milk. Other species that have been detected in fluid milk include Pseudomonas fragi, Pseudomonas lundensis, and Pseudomonas putida (Ternström et al., 1993; Eneroth et al., 2000b; Brown and Luke, 2010).

Another common cause of PPC in fluid milk is contamination with coliforms (Kaloianov and Gogov, 1977; Wessels et al., 1989; Martin et al., 2012). Coliforms are defined not by taxonomic relationships but by common phenotypic characteristics (Martin et al., 2016). Specifically, coliforms are a group of aerobic and facultatively anaerobic, gram-negative, non-spore-forming rods that are capable of fermenting lactose to produce gas and acid within $48 \mathrm{~h}$ at 32 to $35^{\circ} \mathrm{C}$ (Davidson et al., 2004). Most coliforms are within the Enterobacteriaceae family, but at least one organism, Aeromonas, can produce a positive reaction on coliform medium and is in the family Aeromonadaceae (Abbott et al., 2003). Coliforms have been used by the dairy industry for nearly a century as indicators of hygienic conditions in fluid milk (Tortorello, 2003), although there has been some discussion as to whether coliforms are the best indicators to use in fluid milk (Martin et al., 2016). In the United States, coliforms are limited to no more than $10 \mathrm{cfu} / \mathrm{mL}$ in grade 'A' pasteurized milk (FDA, 2015).

Coliforms, because of their method-defined nature, are a very diverse group of microorganisms. A study of microbiological quality of pasteurized fluid milk in New York State from 2001 to 2010 reported that 7.6 to $26.6 \%$ of samples were positive for coliforms in a given year (Martin et al., 2012). In a study of coliform contaminants found in HTST-pasteurized milk from 21 processors in the northeastern United States, Masiello et al. (2016) found that Enterobacter was the most prevalent coliform, compromising $42 \%$ of isolates collected. Hafnia, Citrobacter, Serratia, Raoultella, Buttiauxella, Cedecea, Kluyvera, Leclercia, Pantoea, and Rahnella were also found. Another group found Enterobacter, Klebsiella, and Citrobacter to be the predominant coliform genera in fluid milk and other dairy products in South Africa (Wessels et al., 1989).

In addition to Pseudomonas, other non-coliform gram-negative bacteria linked to fluid milk spoilage are known to contaminate HTST fluid milk, including Aeromonas, Flavobacterium, Alcaligenes, Acinetobacter, and others (Sørhaug and Stepaniak, 1997). Like Pseudomonas and coliforms, this group of bacteria has been shown to include several species and strains that can grow at low temperatures and produce a variety of enzymes that lead to fluid milk degradation (Michener and Elliott, 1964). Non-coliform Enterobacteriaceae are

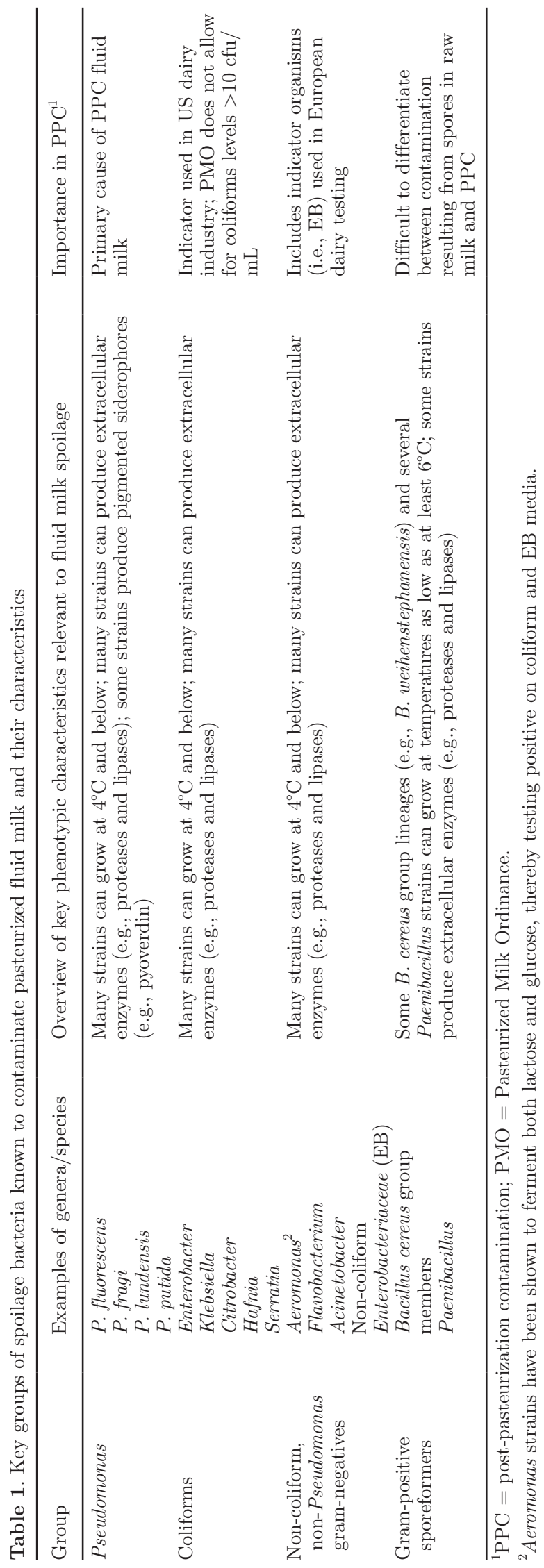

Journal of Dairy Science Vol. 101 No. 1, 2018 
an important group of bacteria in this category and include organisms such as Proteus (Hervert et al., 2016), which are less frequent contaminants in pasteurized fluid milk. Also in this group are bacteria belonging to genera that include strains that ferment lactose (coliforms) and those that do not (non-coliform). A recent study that surveyed growth of Enterobacteriaceae (EB) and coliforms isolated from dairy products on EB and Coliform Petrifilm (3M, Minneapolis, MN) showed that even some strains from genera well known as coliforms do not ferment lactose and therefore do not meet the criteria to be coliforms (Hervert et al., 2016). For example, the authors reported that, of 10 Rahnella isolates tested, only 6 were able to ferment lactose (Hervert et al., 2016). Rahnella has been implicated in a smoky/ phenolic defect in chocolate milk as a result of guaiacol production (Jensen et al., 2001). These strain variations highlight one reason some groups advocate using EB or total gram-negative testing as more comprehensive indicators of PPC.

Gram-positive bacteria, including aerobic grampositive sporeformers, are also capable of contaminating milk after pasteurization; however, several grampositive bacteria also survive pasteurization, either in vegetative (e.g., Micrococcus; Gleeson et al., 2013) or spore form (e.g., Paenibacillus; Postollec et al., 2012), making it more complicated to determine whether these types of organisms, when found in finished products, originated from raw milk or PPC. A study conducted in Brazil showed that the same subtypes, as determined by ribotyping, of Bacillus cereus were found in finished products and on equipment swabs downstream from the pasteurizer (Salustiano et al., 2009). A similar study used randomly amplified polymorphic DNA (RAPD) to assess subtypes of Bacillus found in fluid milk along various points in 2 processing facilities in Sweden and in corresponding sealed consumer packages. The authors found that some RAPD types were found in consumer packages and in samples after the pasteurizer, but not in samples taken before the pasteurizer, concluding that these types were evidence of PPC (Eneroth et al., 2001). Although these studies do not necessarily prove that Bacillus were introduced by PPC in these cases, they do raise the possibility of PPC with Bacillus and other sporeformers and point to need for additional studies on occurrence and importance of PPC with spore-forming bacteria that cause fluid milk spoilage. If PPC with aerobic gram-positive sporeformers is suspected, the subtyping tools used by these authors (i.e., ribotyping and RAPD), and others discussed below, may be useful in determining whether the contamination occurred at the farm or processing plant.

\section{PPC HAS A SIGNIFICANT EFFECT ON BACTERIAL LEVELS AND SENSORIAL PROPERTIES OF FLUID MILK}

It has been extensively reported that fluid milk with reduced shelf life (i.e., $<10-14 d$ ) is virtually always characterized by presence and growth of microorganisms introduced by PPC (Schröder et al., 1982; Griffiths et al., 1988; Ranieri and Boor, 2009; Martin et al., 2012). In these studies, shelf life was defined either microbiologically (number of days under refrigerated storage to reach the PMO limit of 20,000 cfu/ $\mathrm{mL}$ ) or by milk defect judging or sensory evaluation. In the absence of PPC, the limiting biological agents in fluid milk are aerobic psychrotolerant spore-forming bacteria that originate in the farm environment, enter the fluid milk continuum on the farm, survive pasteurization in spore form, and then grow at refrigeration temperatures (Huck et al., 2008). Fluid milk reaching spoilage levels due to aerobic spore-forming bacteria typically have shelf lives of greater than $14 \mathrm{~d}$ (Ranieri and Boor, 2009), in contrast to those with PPC, which routinely reach spoilage levels after 7 to $10 \mathrm{~d}$ of refrigerated storage at around $6^{\circ} \mathrm{C}$ (Ranieri and Boor, 2009). Martin et al. (2012), in a survey of fluid milk over a 10 -yr period in New York State, indicated that samples with PPC, specifically with coliform bacteria, showed significantly higher total bacteria counts at $14 \mathrm{~d}$ after processing than samples with no coliform contamination. Another study showed that many psychrotolerant coliform strains are capable of growing more than 5 log in refrigerated fluid milk at $6^{\circ} \mathrm{C}$ over $10 \mathrm{~d}$ (Masiello et al., 2016). Others have shown that, even at refrigeration temperatures of $4^{\circ} \mathrm{C}$ and at temperatures below $0^{\circ} \mathrm{C}$, Pseudomonas and other psychrotolerant post-pasteurization contaminants are capable of growing in and spoiling (i.e., producing degradative enzymes) pasteurized fluid milk (Michener and Elliott, 1964; Sørhaug and Stepaniak, 1997). Although some spoilage microorganisms can grow in milk even at temperatures of $4^{\circ} \mathrm{C}$ and below, storage temperature is a known factor affecting growth rates of Pseudomonas and other gram-negative contaminants (e.g., coliforms) in pasteurized fluid milk (Schröder et al., 1982). Temperature may also play a role in the relative populations of psychrotolerant contaminants in fluid milk over shelf life (Schröder et al., 1982). For example, Schröder et al. (1982) found that the predominant psychrotolerant organisms present in pasteurized fluid milk from 4 processors in the UK after storage at $5^{\circ} \mathrm{C}$ were gram-negative rods, whereas after storage at $11^{\circ} \mathrm{C}$, the predominant organisms detected were psychrotolerant sporeformers. However, another study found that when PPC was present, there were no 
major differences in the populations found in pasteurized milk held at $6^{\circ} \mathrm{C}$ or at $10^{\circ} \mathrm{C}$ (Griffiths et al., 1988). More research is needed to better understand the effect of storage temperature on specific population changes that occur in fluid milk over its shelf life.

In addition to growth to high numbers during storage, several PPC organisms (e.g., Pseudomonas) also produce a variety of enzymes that lead to sensorial defects in fluid milk. Production of proteases and lipases that break down milk components have been described in Pseudomonas (Corrêa et al., 2011), a variety of coliform bacteria (Masiello et al., 2016), and in psychrotolerant spore-forming bacteria (Trmčić et al., 2015). For example, Dogan and Boor (2003) reported that of 338 Pseudomonas isolates, representing 42 unique ribotypes collected from processed milk, raw milk, and dairy plant environments, $51 \%$ were protease positive, $47 \%$ were lecithinase positive, and $67 \%$ were lipase positive. They further report that enzyme production appeared to be strain dependent, with the majority (69\%) of $P$. fluorescens being positive for all 3 enzymes and $87.5 \%$ of $P$. putida being negative for all 3 enzymes. Another group assessed proteolytic and lipolytic activity of 37 $P$. fluorescens isolates from pasteurized milk and reported that all isolates were positive for protease and lipase activity (Rajmohan et al., 2002). Species and strain variations are consistent with other studies that report that different Pseudomonas species produce different sensory defects in skim and whole milk (Hayes et al., 2002). Specifically, Hayes et al. (2002) found that $P$. putida produced fruity fermented odors, whereas $P$. fluorescens did not. Reports indicate that most enzyme production by Pseudomonas occurs when bacterial concentrations reach $\sim 10^{6} \mathrm{cfu} / \mathrm{mL}$ or higher. However, some strains are known to produce these enzymes at much lower concentrations (i.e., $10^{4} \mathrm{cfu} / \mathrm{mL}$; Law, 1979; Schröder et al., 1982; Sørhaug and Stepaniak, 1997). Psychrotolerant coliforms have also been reported to vary in their ability to produce lipolytic and proteolytic enzymes. Masiello et al. (2016) reported that of 10 Buttiauxella isolates collected from pasteurized fluid milk, none were positive for lipolysis, whereas all Serratia isolates $(\mathrm{n}=17)$ from the same study were positive for lipolysis. Similar to the variation seen between different Pseudomonas species, strains within the same genera of psychrotolerant coliforms also show varying levels of enzyme production. For example, among the 17 Serratia isolates characterized by Masiello et al. (2016), 4 were negative for proteolytic activity, 6 had moderate activity, and 7 were highly proteolytic. Wessels et al. (1989) observed a similar variation in capacity to produce proteolytic and lipolytic enzymes in strains of coliforms isolated from various dairy products in
South Africa. Specifically, they found that some strains of Enterobacter and Klebsiella were proteolytic at $7^{\circ} \mathrm{C}$, whereas some strains of Enterobacter, Klebsiella, and Serratia showed lipolytic activity at $30^{\circ} \mathrm{C}$ (Wessels et al., 1989).

The flavor and odor defects resulting from the production of extracellular enzymes are varied. Hayes and colleagues (2002) investigated the odor defects produced by 6 strains of Pseudomonas (2 strains each of P. fluorescens, P. fragi, and P. putida) and found that odor defects such as fruity, barny, rotten, cheesy, and others were produced and differed by strain, milk fat level (e.g., skim or whole), and time of storage. The accumulation of small peptides resulting from bacterial proteolysis have also been reported to cause bitterness (Ma et al., 2000; Clark et al., 2009) and astringency (Harwalkar et al., 1989). Lipolytic activity, causing the release of free fatty acids, may cause rancidity (Shipe et al., 1978) and unclean and soapy flavors (Dogan and Boor, 2003), all of which are common defects in fluid milk contaminated after pasteurization with psychrotolerant gram-negative bacteria.

In addition to flavor and odor defects generated by PPC organisms in fluid milk, some cause severe body defects as well. A major defect associated with the growth of organisms introduced after pasteurization is coagulation, which can occur via 2 major pathways. The first pathway is via production of acid as a byproduct that destabilizes the protein matrix. Many common PPC organisms, including some strains of Pseudomonas and many psychrotolerant coliforms produce acid and thereby coagulate milk (Komagata, 1961). Another cause of coagulation is via proteolytic activity and it is commonly associated with psychrotolerant gramnegative bacteria such as Pseudomonas (Nörnberg et al., 2010). This defect, typically called "sweet-curdling" because it occurs in the absence of acidification, is also caused by some gram-positive spore-forming bacteria (Collins, 1981). Another body defect associated with PPC is "ropiness," which results from the production of exopolysaccharides that cause the product to develop a slimy consistency. This defect is caused by several organisms, including Klebsiella and other common postpasteurization contaminants (Cheung and Westhoff, 1983). Finally, certain PPC organisms are known to produce pigments that cause color defects in fluid milk (Palleroni, 1984). For example, Evanowski et al. (2017) described a gray pigment defect in conventionally pasteurized fluid milk that was contaminated with Pseudomonas azotoformans. This organism is closely related to Pseudomonas fluorescens, which has been implicated in several color-related defects in dairy products (Martin et al., 2011a; Nogarol et al., 2013). 


\section{PROCESSORS COMMITTED TO REDUCING PPC WILL USE TOTAL GRAM-NEGATIVE TESTING}

In the United States and many countries, indicator organisms are used to determine the hygienic quality of pasteurized milk. Current US standards require total plate counts of less than $20,000 \mathrm{cfu} / \mathrm{mL}$ and coliforms no greater than $10 \mathrm{cfu} / \mathrm{mL}$ in grade 'A' pasteurized fluid milk (FDA, 2015). In Europe, Enterobacteriaceae are the primary indicators used for pasteurized milk and milk products (European Communities Regulation, 2010). Importantly, total plate counts do not provide an indication of PPC because high counts with this method could be due to bacteria surviving HTST (as detailed above) or to PPC. Methods approved for coliform enumeration in grade 'A' pasteurized fluid milk include (1) coliform plate count on violet red bile agar (VRBA); (2) Petrifilm Coliform Count or High Sensitivity Coliform Count (3M, St. Paul, MN); (3) TEMPO CC-Coliform Count (BioMerieux, St. Louis, MO); and (4) Peel Plate E. coli and Coliform and/or Peel Plate E. coli and Coliform High Volume Sensitivity (Charm Sciences Inc., Lawrence, MA; FDA, 2015). These methods, although approved for coliforms, are not able to detect all PPC because they do not detect lactose non-fermenters (e.g., Pseudomonas), which are known to compromise the bulk of PPC. Van Tassell et al. (2012) specifically demonstrated that VRBA, Petrifilm Coliform Count plates, and MacConkey agar were ineffective at recovering a panel of 12 dairy-associated Pseudomonas isolates. However, pour plating with crystal violet tetrazolium agar (CVTA) showed the highest detection efficiency for the presence of PPC (determined by end of shelf life testing for gram-negative bacteria) compared with a nonselective standard plate count agar $\left(R^{2}=0.95\right)$. Another recent study has shown that plating pasteurized fluid milk on CVTA following an enrichment step $\left(21^{\circ} \mathrm{C} / 18 \mathrm{~h}\right)$ resulted in significantly higher detection of PPC than other methods (e.g., plating on coliform medium following the same enrichment protocol; Alles et al., 2016). The primary driver of the increased sensitivity for CVTA-based methods is the ability of CVTA to detect total gram-negative bacteria including Pseudomonas, which represented $\sim 50 \%$ of the isolates identified in milk with PPC by the study cited above (Alles et al., 2016), as well as traditional indicators (i.e., coliforms).

The use of CVTA for detection of total gram-negative bacteria is outlined in the Standard Methods for the Examination of Dairy Products (Frank et al., 1992). Crystal violet has been shown to inhibit gram-positive bacteria while not significantly suppressing gramnegative bacteria (Smith and Witter, 1979) and has been used for detecting PPC since the 1960s (Thomas,
1969). Despite the half century since this method was first used in the dairy industry, very little additional methodological development, in particular in the area of rapid and automated methods, has occurred for detecting total gram-negative bacteria in fluid milk. This is in stark contrast to the numerous methods developed and widely used for detecting total viable organisms and coliforms in fluid milk, including dehydrated film media (Ginn et al., 1986), flow cytometry (Loss et al., 2012), and optical-based detection methods (Firstenberg-Eden et al., 2002). The limited availability of rapid and automated methods for detection and enumeration of total gram-negative bacteria in fluid milk is a major barrier to the dairy industry's ability to quickly identify and resolve contamination events and ultimately deliver the highest quality product to consumers. Further research and development at both the academic and diagnostic industry level is needed to fill this gap.

\section{FILLERS ARE A MAJOR SOURCE OF PPC BUT TRACKING PPC SOURCES REQUIRES DISCRIMINATORY MOLECULAR SUBTYPING METHODS}

Many factors contribute to the occurrence of PPC in fluid milk, including problems with hygienic design of equipment, cleaning and sanitization procedures, preventative maintenance, control of plant air, and prevention of cross contamination. To identify and resolve PPC events, processors must perform root-cause analysis that includes establishing whether the contamination is persistent or transient in nature, as this will inform the necessary steps to resolve the contamination. Persistent contamination occurs when an organism is introduced into, and continues to live in, the facility or equipment over time without being removed by cleaning and sanitation. A common vehicle of persistent contamination is biofilms, which are communities of bacteria that attach to processing equipment and are resistant to cleaning and sanitation, leading to continued contamination of the product over time (Marchand et al., 2012). Many organisms have been found to inhabit biofilms in dairy processing facilities, including gram-positive (e.g., Bacillus) and gram-negative (e.g., Escherichia coli) bacteria (Salustiano et al., 2009; Shi and Zhu, 2009; Simões et al., 2010; Cherif-Antar et al., 2016). Biofilms are likely to occur when cleaning and sanitation and preventative maintenance programs are ineffectively designed or implemented. This may be in the form of dead ends in equipment, incorrect concentrations of cleaning and sanitizing chemicals, and cracked or pitted rubber filler components. Even correctly used clean-in-place systems may allow development of biofilms in dairy processing equipment that 
cannot be subsequently removed (Simões et al., 2010). However, persistent bacterial communities may not necessarily have to represent biofilms; sanitary design issues with equipment and facilities may provide niches where bacteria are protected from sanitizer and survive in "non-biofilm communities." For example, it is conceivable that pipe dead ends may contain planktonic bacterial communities or sessile bacteria without the extracellular matrix that is typical of biofilms.

Filling equipment has been identified by several studies as a primary source of persistent PPC in fluid milk. For example, Eneroth et al. (1998) took samples of HTST fluid milk at various sites along the processing continuum (e.g., silo tank, immediately preceding and following the pasteurizer, buffer tank, filler and consumer package) and found that the majority of PPC was occurring at the filling step. Similarly, another study used molecular subtyping tools, specifically ribotyping, to track the source of Pseudomonas PPC of HTST pasteurized fluid milk to filler nozzles, which had cracks and other evidence of deterioration upon manual compression that were not evident in the nozzles during cleaning and sanitation (Ralyea et al., 1998). A study conducted in the UK showed that although instances of PPC originated from milk storage tanks, the majority of PPC originated at the filling step and occurred at low levels (1-50 psychrotolerant gram-negative bacteria per $100 \mathrm{~mL}$; Schröder, 1984). Gruetzmacher and Bradley (1999) also found that the filling equipment was a major source of PPC. Those authors sampled milk just before it flowed through the filling machine head and immediately after, finding that the milk that had not passed through the filling equipment had a 20-d-longer shelf life at $7^{\circ} \mathrm{C}$ (Gruetzmacher and Bradley, 1999).

Transient contamination occurs when an organism that is present in the equipment or facility is introduced onto food contact surfaces or directly into the product but is subsequently removed with effective cleaning and sanitation. Primary modes of transient contamination are through worker contact, especially when proper handwashing frequency and technique are not adhered to (Montville et al., 2002), and via biological aerosols (Kang and Frank, 1989). Aerosols are suspensions of microscopic solid or liquid particles in air or gas (Kang and Frank, 1989); when they carry bacteria, fungi, or other microorganisms, they are considered biological aerosols. In the case of biological aerosols, contamination that may be present in non-food contact areas (e.g., floors or drains) is aerosolized by a variety of mechanisms, including hose use during production (Kang and Frank, 1989). One study found that hose use, drains, and personnel activity were all associated with an increase in total aerobes and staphylococci found in dairy processing facility air (Ren and Frank,
1992). In addition to hose use causing potential PPC through aerosolization, direct use of water on fillers in dairy plants has been found to be associated with higher levels of PPC (Eneroth et al., 2000a).

Determining the source, type (i.e., persistent vs. transient), and causative agents of PPC cannot be achieved with traditional microbiological methods alone. Molecular subtyping tools, which have been used in source tracking in foodborne disease outbreaks for decades (Sabat et al., 2013), provide a sensitive tool for the dairy industry to track and resolve PPC. Previously used subtyping techniques for tracking PPC include pulsed field gel electrophoresis (PFGE; Martin et al., 2011a), ribotyping (Martin et al., 2011a), multilocus sequence typing (MLST; Andreani et al., 2014), RAPD (Eneroth et al., 2000a), and DNA-based sequencing techniques (e.g., rpoB allelic typing; Huck et al., 2007). For example, Martin et al. (2011a) used DNA sequencing, ribotyping, and PFGE as molecular subtyping tools to track PPC causing a blue discoloration in a fresh, low-acid cheese product and identified environmental sources that were responsible for contamination of the finished products. Ultimately, PFGE was found to be sufficiently discriminatory to distinguish between $P$. fluorescens strains capable of causing the defect and those that did not, as well as to determine that the source of the organism was an agitator track above a cheese vat. Likewise, RAPD was used to identify the primary sources of gram-negative contamination in 3 dairies in Sweden (Eneroth et al., 2000b). Those authors found that the same persistent RAPD types (most of which were identified as Pseudomonas) were found in condensed water on the filling nozzles, in wastewater at the bottom of the filling machine, and in the air surrounding the filling machine as were found in pasteurized packaged milk (Eneroth et al., 2000b).

Finally, in the case of suspected PPC with organisms that can both originate in raw milk and potentially contaminate product after pasteurization (i.e., grampositive sporeformers such as Paenibacillus), these highly sensitive molecular subtyping tools are necessary to distinguish the source of the contamination. A 2007 study (Huck et al., 2007) demonstrated that gram-positive spore-forming bacteria can be tracked from the farm throughout a HTST fluid milk processing facility, and that certain rpo $B$ allelic types appear to be introduced at various points throughout the process. However, although single-gene methods (such as rро $B$ allelic typing) provide for good characterization and identification, these methods typically have limited discriminatory power and hence may not always be the best source-tracking tool. Interestingly, another study showed that unique RAPD subtypes of gram-positive sporeformers (Bacillus cereus s.l. and Paenibacillus 
odorifer) were detected over time in extended-shelf-life fluid milk products processed in Germany but were never isolated from raw bulk tank milk (Doll et al., 2017). Although this finding may suggest that contamination with these organisms represented PPC, it could also be due to difficulties detecting low levels of these organisms in raw milk. These studies highlight the need for sensitive and discriminatory subtyping tools to better identify and characterize PPC sources and transmission of both gram-positive and gram-negative spoilage organisms. Although application of emerging whole-genome sequencing methods will likely provide valuable tools for these purposes, the importance of well-designed sampling plans and schemes cannot be underemphasized.

\section{CONCLUSIONS}

Although PPC remains an important cause of fluid milk spoilage, some processing facilities have been highly successful at minimizing PPC (Martin et al., 2012), indicating that effective control is possible, even though contamination of a milk container with a single organism that can grow at refrigeration temperatures is sufficient to cause product spoilage over shelf life. Efforts to develop and deploy more effective tools to detect PPC, trace it to a source, and ultimately prevent PPC are, however, essential in improving the quality and shelf life of HTST-pasteurized fluid milk. Specific areas of need include (1) development of better methods for detection and trace-back of PPC; (2) validation and implementation of improved procedures to prevent PPC (e.g., sanitation standard operating procedures, procedures for mid-shift clean-up); and (3) sanitary equipment design. Lessons learned from the control of environmentally transmitted foodborne pathogens (primarily Listeria monocytogenes) might be translatable to improved control of PPC. For example, the use of "seek and destroy" type approaches developed for Listeria control (Malley et al., 2015) could be modified to identify and eliminate environmental sources of PPC. Similarly, data indicating that mid-shift clean-up actually increases the risk of Listeria contamination could be applied to PPC and spur further studies on the effectiveness of different in process cleaning strategies that may currently be used in HTST plants.

\section{ACKNOWLEDGMENTS}

The authors acknowledge the role that the New York State Dairy Promotion Advisory Board (Albany, NY) has played in their continued support of research aimed at improving the quality and safety of dairy products in New York State and beyond.

\section{REFERENCES}

Abbott, S. L., W. K. Cheung, and J. M. Janda. 2003. The genus Aeromonas: Biochemical characteristics, atypical reactions, and phenotypic identification schemes. J. Clin. Microbiol. 41:23482357.

Alles, A., M. Wiedmann, and N. H. Martin. 2016. Rapid Detection and Characterization of Post-processing Contaminants in Conventionally Pasteurized Fluid Milk. In Proc. International Association for Food Protection, St. Louis, MO.

Andreani, N. A., M. E. Martino, L. Fasolato, L. Carraro, F. Montemurro, R. Mioni, P. Bordin, and B. Cardazzo. 2014. Tracking the blue: A MLST approach to characterise the Pseudomonas fluorescens group. Food Microbiol. 39:116-126.

Brown, A. G., and R. K. J. Luke. 2010. Siderophore production and utilization by milk spoilage Pseudomonas species. J. Dairy Sci. 93:1355-1363.

Champagne, C. P., R. R. Laing, D. Roy, A. A. Mafu, M. W. Griffiths, and C. White. 1994. Psychrotrophs in dairy products: Their effects and their control. Crit. Rev. Food Sci. Nutr. 34:1-30.

Cherif-Antar, A., B. Moussa-Boudjemâa, N. Didouh, K. Medjahdi, B. Mayo, and A. B. Flórez. 2016. Diversity and biofilm-forming capability of bacteria recovered from stainless steel pipes of a milkprocessing dairy plant. Dairy Sci. Technol. 96:27-38.

Cheung, B. A., and D. C. Westhoff. 1983. Isolation and identification of ropy bacteria in raw milk. J. Dairy Sci. 66:1825-1834.

Clark, S., M. Costello, M. Drake, and F. Bodyfelt. 2009. The sensory evaluation of dairy products. 2nd ed. Springer, New York, NY.

Collins, E. B. 1981. Heat resistant psychrotrophic microorganisms. J. Dairy Sci. 64:157-160.

Corrêa, A. P. F., D. J. Daroit, R. V. Velho, and A. Brandelli. 2011. Hydrolytic potential of a psychrotrophic Pseudomonas isolated from refrigerated raw milk. Braz. J. Microbiol. 42:1479-1484.

Davidson, P., L. Roth, and S. Gambrel-Lenarz. 2004. Coliform and other indicator bacteria. Pages 187-226 in Standard Methods for the Examination of Dairy Products. 17th ed. H. M. Wehr and J. F. Frank, ed. American Public Health Association, Washington, DC.

Deeth, H. C., T. Khusniati, N. Datta, and R. B. Wallace. 2002. Spoilage patterns of skim and whole milks. J. Dairy Res. 69:227-241.

Dogan, B., and K. J. Boor. 2003. Genetic diversity and spoilage potentials among Pseudomonas spp. isolated from fluid milk products and dairy processing plants. Appl. Environ. Microbiol. 69:130-138.

Doll, E. V., S. Scherer, and M. Wenning. 2017. Spoilage of microfiltered and pasteurized extended shelf life milk is mainly induced by psychrotolerant spore-forming bacteria that often originate from recontamination. Front. Microbiol. 8:135.

Eneroth, A., S. Ahrné, and G. Molin. 2000a. Contamination of milk with Gram-negative spoilage bacteria during filling of retail containers. Int. J. Food Microbiol. 57:99-106.

Eneroth, Å., S. Ahrné, and G. Molin. 2000b. Contamination routes of Gram-negative spoilage bacteria in the production of pasteurised milk, evaluated by randomly amplified polymorphic DNA (RAPD). Int. Dairy J. 10:325-331.

Eneroth, A.., A. Christiansson, J. Brendehaug, and G. Molin. 1998 Critical contamination sites in the production line of pasteurised milk, with reference to the psychrotrophic spoilage flora. Int. Dairy J. 8:829-834.

Eneroth, A., B. Svensson, G. Molin, and A. Christiansson. 2001. Contamination of pasteurized milk by Bacillus cereus in the filling machine. J. Dairy Res. 68:189-196.

European Communities Regulation. 2010. European communities regulation commission regulation on microbiological criteria for foodstuffs. Off. J. Eur. Union 107:9-11.

Evanowski, R. L., S. J. Reichler, D. J. Kent, N. H. Martin, K. J. Boor, and M. Wiedmann. 2017. Short communication: Pseudomonas azotoformans causes gray discoloration in HTST fluid milk. J. Dairy Sci.100:7906-7909.

FDA. 2015. Standards for grade "A" milk and milk products. Pages 34-35 in Grade "A" Pasteurized Milk Ordinance. Standards for grade "A" milk and milk products. US Department of Health and Human Services, Public Health Service, Washington, DC. 
Firstenberg-Eden, R., D. L. Foti, S. T. McDougal, and J. Baker. 2002. Optical instrument for the rapid detection of microorganisms in dairy products. Int. Dairy J. 12:225-232.

Frank, J., G. Christen, and L. Bullerman. 1992. Tests for groups of microorganisms. Pages 239-242 in Standard Methods for the Examination of Dairy Products. 16th ed. R. T. Marshall, ed. American Public Health Association, Washington, DC.

Ginn, R. E., V. Packard, and T. Fox. 1986. Enumeration of total bacteria and coliforms in milk by dry rehydratable film methods: Collaborative study. J. Assoc. Off. Anal. Chem. 69:527-531.

Gleeson, D., A. O'Connell, and K. Jordan. 2013. Review of potential sources and control of thermoduric bacteria in bulk-tank milk. Ir. J. Agric. Food Res. 52:217-227.

Gram, L., L. Ravn, M. Rasch, J. B. Bruhn, A. B. Christensen, and M. Givskov. 2002. Food spoilage - interactions between food spoilage bacteria. Int. J. Food Microbiol. 78:79-97.

Griffiths, M. W., J. D. Phillips, I. G. West, and D. D. Muir. 1988. The effect of extended low-temperature storage of raw milk on the quality of pasteurized and UHT milk. Food Microbiol. 5:75-87.

Gruetzmacher, T. J., and R. L. Bradley Jr.. 1999. Identification and control of processing variables that affect the quality and safety of fluid milk. J. Food Prot. 62:625-631.

Harwalkar, V. R., B. Boutin-Muma, H. Cholette, R. McKellar, D. Emmons, and G. Klassen. 1989. Isolation and partial purification of astringent compounds from ultra-high temperature sterilized milk. J. Dairy Res. 56:367-373.

Hayes, W., C. H. White, and M. A. Drake. 2002. Sensory aroma characteristics of milk spoilage by Pseudomonas species. J. Food Sci. $67: 448-454$.

Hervert, C. J., A. Alles, N. Martin, K. Boor, and M. Wiedmann. 2016. Evaluation of different methods to detect microbial hygiene indicators relevant in the dairy industry. J. Dairy Sci. 99:7033-7042.

Holsinger, V. H., K. T. Rajkowski, and J. R. Stabel. 1997. Milk pasteurisation and safety: A brief history and update. Rev. Sci. Tech. $16: 441-451$

Huck, J. R., B. H. Hammond, S. C. Murphy, N. H. Woodcock, and K. J. Boor. 2007. Tracking spore-forming bacterial contaminants in fluid milk-processing systems. J. Dairy Sci. 90:4872-4883.

Huck, J. R., M. Sonnen, and K. J. Boor. 2008. Tracking heat-resistant, cold-thriving fluid milk spoilage bacteria from farm to packaged product. J. Dairy Sci. 91:1218-1228.

Ivy, R. A., M. L. Ranieri, N. H. Martin, H. C. den Bakker, B. M. Xavier, M. Wiedmann, and K. J. Boor. 2012. Identification and characterization of psychrotolerant sporeformers associated with fluid milk production and processing. Appl. Environ. Microbiol. 78:1853-1864.

Jensen, N., P. Varelis, and F. B. Whitfield. 2001. Formation of guaiacol in chocolate milk by the psychrotrophic bacterium Rahnella aquatilis. Lett. Appl. Microbiol. 33:339-343.

Juffs, H. S. 1973. Identification of Pseudomonas spp. isolated from milk produced in South Eastern Queensland. J. Appl. Bacteriol. 36:585-598.

Kaloianov, I., and I. Gogov. 1977. (Coliform bacteria in raw and pasteurized milk). Vet. Med. Nauki 14:46-52. [Article in Bulgarian]

Kang, Y.-J., and J. F. Frank. 1989. Biological aerosols: A review of airborne contamination and its measurement in dairy processing plants. J. Food Prot. 52:512-524.

Komagata, K. 1961. Differentiation of genus Pseudomonas and related aerobic bacteria. J. Gen. Appl. Microbiol. 7:282-299.

Law, B. A. 1979. Enzymes of psychrotrophic bacteria and their effects on milk and milk products. J. Dairy Res. 46:573-588.

Loss, G., S. Apprich, W. Kneifel, E. von Mutius, J. Genuneit, and C. Braun-Fahrländer. 2012. Short communication: Appropriate and alternative methods to determine viable bacterial counts in cow milk samples. J. Dairy Sci. 95:2916-2918.

Ma, Y., C. Ryan, D. Barbano, D. Galton, M. Rudan, and K. Boor. 2000. Effects of somatic cell count on quality and shelf-life of pasteurized fluid milk. J. Dairy Sci. 83:264-274.

Malley, T. J., J. Butts, and M. Wiedmann. 2015. Seek and destroy process: Listeria monocytogenes process controls in the ready-toeat meat and poultry industry. J. Food Prot. 78:436-445.
Marchand, S., J. D. Block, V. D. Jonghe, A. Coorevits, M. Heyndrickx, and L. Herman. 2012. Biofilm formation in milk production and processing environments; influence on milk quality and safety. Compr. Rev. Food Sci. Food Saf. 11:133-147.

Martin, N. H., N. R. Carey, S. C. Murphy, M. Wiedmann, and K. J. Boor. 2012. A decade of improvement: New York State fluid milk quality. J. Dairy Sci. 95:7384-7390.

Martin, N. H., S. C. Murphy, R. D. Ralyea, M. Wiedmann, and K. J. Boor. 2011a. When cheese gets the blues: Pseudomonas fluorescens as the causative agent of cheese spoilage. J. Dairy Sci. 94:3176-3183.

Martin, N. H., M. L. Ranieri, S. C. Murphy, R. D. Ralyea, M. Wiedmann, and K. J. Boor. 2011b. Results from raw milk microbiological tests do not predict the shelf-life performance of commercially pasteurized fluid milk. J. Dairy Sci. 94:1211-1222.

Martin, N. H., A. Trmčić, T.-H. Hsieh, K. J. Boor, and M. Wiedmann. 2016. The evolving role of coliforms as indicators of unhygienic processing conditions in dairy foods. Front. Microbiol. 7:1549.

Masiello, S. N., N. Martin, A. Trmčić, M. Wiedmann, and K. Boor. 2016. Identification and characterization of psychrotolerant coliform bacteria isolated from pasteurized fluid milk. J. Dairy Sci. 99:130-140.

Michener, H. D., and R. P. Elliott. 1964. Minimum growth temperatures for food-poisoning, fecal-indicator, and psychrophilic microorganisms. Adv. Food Res. 13:349-396.

Montville, R., Y. Chen, and D. W. Schaffner. 2002. Risk assessment of hand washing efficacy using literature and experimental data. Int. J. Food Microbiol. 73:305-313.

Nogarol, C., P. Acutis, D. Bianchi, C. Maurella, S. Peletto, S. Gallina, D. Adriano, F. Zuccon, S. Borrello, and M. Caramelli. 2013. Molecular characterization of Pseudomonas fluorescens isolates involved in the Italian "blue mozzarella" event. J. Food Prot. 76:500-504

Nörnberg, M. F. B. L., R. S. C. Friedrich, R. D. N. Weiss, E. C. Tondo, and A. Brandelli. 2010. Proteolytic activity among psychrotrophic bacteria isolated from refrigerated raw milk. Int. J. Dairy Technol. $63: 41-46$.

Palleroni, N. J. 1984. Pseudomonas. In Bergey's Manual of Systematics of Archaea and Bacteria. N. R. Krieg and J. C. Holt, ed. Williams and Wilkins, Baltimore, MD.

Postollec, F., A. G. Mathot, M. Bernard, M. L. Divanac'h, S. Pavan, and D. Sohier. 2012. Tracking spore-forming bacteria in food: from natural biodiversity to selection by processes. Int. J. Food Microbiol. 158:1-8.

Rajmohan, S., C. E. R. Dodd, and W. M. Waites. 2002. Enzymes from isolates of Pseudomonas fluorescens involved in food spoilage. J. Appl. Microbiol. 93:205-213.

Ralyea, R. D., M. Wiedmann, and K. J. Boor. 1998. Bacterial tracking in a dairy production system using phenotypic and ribotyping methods. J. Food Prot. 61:1336-1340.

Ranieri, M. L., and K. Boor. 2009. Short communication: Bacterial ecology of high-temperature, short-time pasteurized milk processed in the United States. J. Dairy Sci. 92:4833-4840.

Ren, T.-J., and J. F. Frank. 1992. Sampling of microbial aerosols at various locations in fluid milk and ice cream plants. J. Food Prot. $55: 279-283$.

Sabat, A. J., A. Budimir, D. Nashev, R. Sá-Leão, J. Van Dijl, F. Laurent, H. Grundmann, and A. Friedrich., and ESCMID Study Group of Epidemiological Markers (ESGEM). 2013. Overview of molecular typing methods for outbreak detection and epidemiological surveillance. Euro Surveill. 18:20380.

Salustiano, V. C., N. J. Andrade, N. F. F. Soares, J. C. Lima, P. C. Bernardes, L. M. P. Luiz, and P. E. Fernandes. 2009. Contamination of milk with Bacillus cereus by post-pasteurization surface exposure as evaluated by automated ribotyping. Food Contr. 20:439-442.

Schröder, M. J. 1984. Origins and levels of post pasteurization contamination of milk in the dairy and their effects on keeping quality. J. Dairy Res. 51:59-67.

Schröder, M. J. A., C. M. Cousins, and C. H. McKinnon. 1982. Effect of psychrotrophic post-pasteurization contamination on the keep- 
ing quality at 11 and $5{ }^{\circ} \mathrm{C}$ of HTST-pasteurized milk in the UK. J. Dairy Res. 49:619-630.

Shi, X., and X. Zhu. 2009. Biofilm formation and food safety in food industries. Trends Food Sci. Technol. 20:407-413.

Shipe, W., R. Bassette, D. Deane, W. Dunkley, E. Hammond, W. Harper, D. Kleyn, M. Morgan, J. Nelson, and R. Scanlan. 1978. Off flavors of milk: Nomenclature, standards, and bibliography. J. Dairy Sci. 61:855-869.

Simões, M., L. C. Simões, and M. J. Vieira. 2010. A review of current and emergent biofilm control strategies. Lebensm. Wiss. Technol. 43:573-583.

Smith, R. S. 1920. Bacterial control in milk plants. J. Dairy Sci. 3:540554

Smith, T. L., and L. Witter. 1979. Evaluation of inhibitors for rapid enumeration of psychrotrophic bacteria. J. Food Prot. 42:158-160.

Sørhaug, T., and L. Stepaniak. 1997. Psychrotrophs and their enzymes in milk and dairy products: Quality aspects. Trends Food Sci Technol. 8:35-41.

Stevenson, R. G., M. T. Rowe, G. B. Wisdom, and D. Kilpatrick. 2003. Growth kinetics and hydrolytic enzyme production of Pseudomonas spp. isolated from pasteurized milk. J. Dairy Res. 70:293-296.

Ternström, A., A. M. Lindberg, and G. Molin. 1993. Classification of the spoilage flora of raw and pasteurized bovine milk, with special reference to Pseudomonas and Bacillus. J. Appl. Bacteriol. $75: 25-34$.

Thomas, S. B. 1969. Methods of assessing the psychrotrophic bacterial content of milk. J. Appl. Bacteriol. 32:269-296.

Tortorello, M. L. 2003. Indicator organisms for safety and quality - Uses and methods for detection: minireview. J. AOAC Int. $86: 1208-1217$

Trmčić, A., N. H. Martin, K. J. Boor, and M. Wiedmann. 2015. A standard bacterial isolate set for research on contemporary dairy spoilage. J. Dairy Sci. 98:5806-5817.

Van Tassell, J. A., N. H. Martin, S. C. Murphy, M. Wiedmann, K. J. Boor, and R. A. Ivy. 2012. Evaluation of various selective media for the detection of Pseudomonas species in pasteurized milk. J. Dairy Sci. 95:1568-1574.

Villamiel, M., and P. de Jong. 2000. Inactivation of Pseudomonas fluorescens and Streptococcus thermophilus in Trypticase ${ }^{\circledR}$ Soy Broth and total bacteria in milk by continuous-flow ultrasonic treatment and conventional heating. J. Food Eng. 45:171-179.

Wessels, D., P. J. Jooste, and J. F. Mostert. 1989. Psychrotrophic, proteolytic and lipolytic properties of Enterobacteriaceae isolated from milk and dairy products. Int. J. Food Microbiol. 9:79-83. 